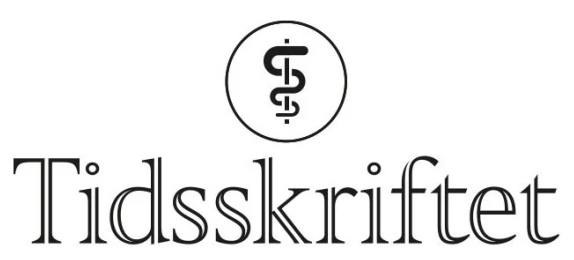

DEN NORSKE LEGEFORENING

\title{
Rettelse: Covid-19 hos pasienter med kronisk inflammatorisk leddsykdom
}

RETTELSE

TONE WIKENE NYSTAD

KARL OVE HUFTHAMMER

EIRIK ALNES BUANES

KJARTAN BRYNE

BJøRG-TILDE SVANES FEVANG

Tidsskr Nor Legeforen 2021; 141: 1350-6.

I Tidsskriftet nr. 14/2021, s. 1352 skal det i tabellteksten til Tabell 2 stå: Det var en generell underhyppighet av smitte blant NorArtritt-pasienter (...).

Vi beklager feilen, den er rettet på nett.

Publisert: 20. oktober 2021. Tidsskr Nor Legeforen. DOI:10.4045/tidsskr.21.0727

(C) Tidsskrift for Den norske legeforening 2023. Lastet ned fra tidsskriftet.no 26. april 2023. 